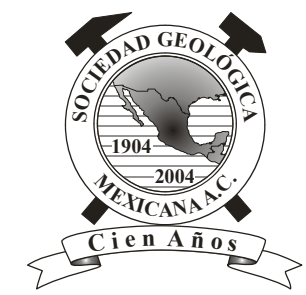

\title{
Late Paleocene Cancellariidae (Gastropoda: Neogastropoda) from Baja California, Mexico
}

\author{
María del Carmen Perrilliat ${ }^{1, *}$, Alejandro Cristín ${ }^{2}$ \\ ${ }^{1}$ Instituto de Geología, Universidad Nacional Autónoma de México, Ciudad Universitaria, 04510 CDMX, México. \\ ${ }^{2}$ Posgrado en Ciencias de la Tierra, Instituto de Geología, Universidad Nacional Autónoma de México, CDMX \\ *mariacp@geologia.unam.mx
}

\begin{abstract}
Four gastropod species including two new ones, belonging to the family Cancellariidae, of the genus Cancellaria, are described and illustrated for the late Paleocene Sepultura Formation in Baja California, northwestern Mexico. The new species Cancellaria bajaensis and Cancellaria paleocenica are established from well preserved specimens.
\end{abstract}

Key words: cancellariid gastropods, late Paleocene, Baja California, Mexico.

Resumen

Se describen e ilustran cuatro especies de canceláridos del género Cancellaria del Paleoceno tardio, provenientes de la Formación Sepultura en la región noroeste de Baja California. Dos especies nuevas, Cancellaria bajaensis y Cancellaria paleocenica, se describen con base en especimenes bien conservados.

Palabras clave: canceláridos, Paleoceno tardio, Baja California, México.

\section{Introduction}

The purpose of this paper is to report the presence of the gastropod genus Cancellaria from a late Paleocene locality in the Sepultura Formation, Baja California, Mexico.

The genus belongs to the family Cancellariidae, Clade Neogastropoda (Bouchet et al., 2005), commonly known as nutmeg snails.

The extensive molluscan gastropod fauna from Mesa San Carlos, Sepultura Formation, Baja California, Mexico (Figure 1), was collected in the years 1986 and 1987 and the fauna studied is based in part on Paredes-Mejía (1989) unpublished Ph.D. Thesis, Purdue University.

Marine deposits of Paleocene age are present in the coastal ranges from North California southward to Baja California, Mexico (Perrilliat, 2013a, p. 179), the Sepultura
Formation for which the name was proposed by Santillán and Barrera (1930).

The first paper that mentioned fossils from Baja California of Paleocene age is by Emmons and Merrill (1894, p. 51). The only described and illustrated Paleocene molluscan faunas from Baja California are those of Zinsmeister and Paredes-Mejía (1988), Squires (1988), Paredes-Mejía (1989), Squires et al. (1989), and Squires and Saul (2006).

The molluscan gastropod fauna in Mesa San Carlos was reported by Perrilliat (2013a, 2013b). She reported the families Trochidae, Solariellidae, Cerithiidae, Turritellidae, Cypraeidae, Ovulidae, Ficidae, Naticidae, Tornidae, Strombidae, Aporrhaidae, Ranellidae, Epitoniidae and Architectonicidae.

The family Cancellariidae has representatives of 
the genera Cancellaria, Bonellitia, and Paladmete in the Cretaceous and Eocene of the West Coast of North America. In the Cretaceous of California two species have been described: Cancellaria turneri White, 1889, and Cancellaria simiana Hanna, 1924.

No species from the Paleocene of California have been described. Cancellaria bournei Hanna, 1927, and Cancellaria vespertina Anderson, 1905 have been described from the Eocene of California and Cancellaria vetusta Gabb, $\mathbf{1 8 6 6}$ is present in the Tertiary of California.

The genus Bonellitia is present in the Eocene of California by Bonellitia (Admetula) paucivaricata (Gabb, 1864) and Bonellitia megapex Vokes, 1939, and Paladmete perforata (Gabb, 1864) from the Cretaceous of California.

The Baja California specimens are not similar to any of these species.

The composition of this fauna compared with faunas of the same age in north and central California shows that the Mesa San Carlos area is characterized by tropical conditions.

The molluscan material discussed in this work comes from Mesa San Carlos Purdue University localities PU1300-2, 1302, 1305, 1307, 1320, and 1334. (Figure 1).

The studied material is deposited in the Museo Ma. del Carmen Perrilliat M., Colección Nacional de Paleontología, Instituto de Geología, Universidad Nacional Autónoma de México. Types are included in the Type Collection and classified under the acronym IGM (Instituto de Geología). The localities are registered in the locality catalogue of the Instituto de Geología, Universidad Nacional Autónoma de México. The classification herein follows that of Bouchet et al. (2005).

\section{Localities}

PU 1300-2 - Elevation $350 \mathrm{~m}, 1.6 \mathrm{~km}$ north and $3.7 \mathrm{~km}$ east of intersection of Cajiloa Creek with road from Mexico Highway 1 to San Carlos, at easternmost part of the southern branch of Cajiloa Creek, northwestern flank of Mesa San Carlos, Baja California. Locality $5 \mathrm{~m}$ stratigraphically above localities PU 1305, PU 1306 and PU 1307. Mesa San Carlos 2, Instituto de Geología IGM 3853.

PU $1302-1.6 \mathrm{~km}$ north and $3.7 \mathrm{~km}$ east of intersection of Cajiloa Creek with road from Mexico Highway 1 to San Carlos, at easternmost part of the southern branch of Cajiloa Creek, northwestern flank of Mesa San Carlos, Baja California. Mesa San Carlos 4, Instituto de Geología IGM 3855.

PU 1305 - Elevation 347 m, $1.65 \mathrm{~km}$ north and $3.6 \mathrm{~km}$ east of intersection of Cajiloa Creek with road from Mexico Highway 1 to San Carlos, at easternmost part of the southern branch of Cajiloa Creek, northwestern flank of Mesa San Carlos, Baja California. Locality is the same stratigraphic horizon as locality PU 1307. Mesa San Carlos 5, Instituto de Geología IGM 3856.

PU 1307 - Elevation 347 m, a few meters east of locality

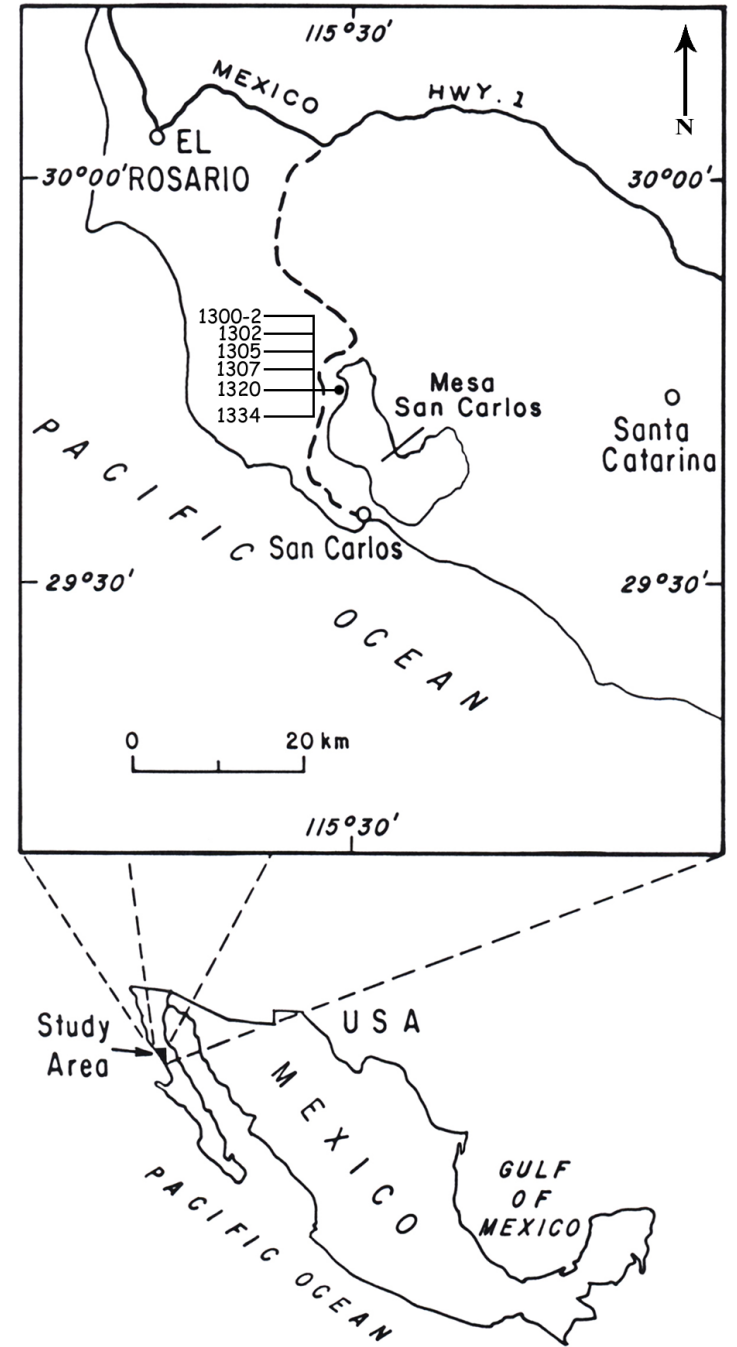

Figure 1. Location map of Mesa San Carlos, Baja California, with Purdue University (PU) collecting localities.

PU 1306 and same stratigraphic horizon as locality PU 1305. Mesa San Carlos 7, Instituto de Geología IGM 3858.

PU 1320 - Mesa San Carlos, Baja California. Instituto de Geología IGM 3483.

PU 1334 - Float material along the southern branch of Cajiloa Creek, northwestern flank of Mesa San Carlos, Baja California. Mesa San Carlos 11, Instituto de Geología IGM 3862.

For more detailed information about the localities see Paredes-Mejía (1989: 455).

\section{Systematic Paleontology}

Clade Neogastropoda

Superfamily Cancellarioidea Forbes and Hanley, 1851

Family Cancellariidae Forbes and Hanley, 1851 Genus Cancellaria Lamarck, 1799 
Type species: by monotypy, Voluta reticulata Linnaeus, 1767. Recent. Caribbean.

\section{Cancellaria bajaensis sp. nov.} Figures 2a-d

Cancellaria n. sp. A. Paredes-Mejía, 1989, p. 386, pl. 16, fig. 15-18.

Diagnosis: Shell medium-sized, subglobose. Sculpture of strong axial ribs.

Description: Shell medium-sized, moderately thick, subglobose. Protoconch of one and a half whorls. Teleoconch of four convex whorls. Suture impressed. Sculpture of first whorl with eight rounded axial ribs, second and third whorls with 12 axial ribs and 12 spiral ribs that cross over the axial ribs; last whorl with 12 axial ribs that become subdued at siphonal canal, and about 35 spiral ribs that cross over the axial ribs. Aperture broad, outer lip thin, columellar lip covered by inductura, columella with two weak folds; siphonal canal straight.

Etymology: The species name refers to the state of Baja California, Mexico.

Types: Holotype IGM 4539, paratype IGM 4540.

Measurements: Holotype IGM 4539, height 22.3, diameter $18.2 \mathrm{~mm}$; paratype IGM 4540, height 21.8 , diameter $17.4 \mathrm{~mm}$.

Occurrence: PU loc 1302.

Remarks: The Mexican specimens differ from Cancellaria simiana Hanna (1924, p. 160), from the Cretaceous of Bell's Canyon, Simi Hills, Los Angeles County, California, in being more convex, and in having higher teleoconch whorls, stronger axial ribs, and a straighter siphonal canal.

\section{Cancellaria paleocenica sp. nov.} Figures $2 \mathrm{e}-\mathrm{j}$

Cancellaria n. sp. B. Paredes-Mejía, 1989, p. 387, pl. 16, fig. 19-24.

Diagnosis: Shell medium-sized, fusiform. Last whorl with a shoulder, in the middle a depressed area with spiral threads, and the anterior part of the whorl with axial and spiral ribs.

Description: Shell medium sized, moderately thick, fusiform. Protoconch of two and a half whorls, dome shaped. Teleoconch of four whorls. Suture canaliculated. Sculpture of first whorl with weak axial ribs crossed over by two spiral ribs, giving ribs appearance of nodes. Second whorl with a posterior nodose collar next to the suture, and three weak spiral threads. The third and fourth whorls with a posterior shoulder with 15 axial ribs and spiral threads, the middle part of the whorl is depressed with six spiral ribs intercalated with weak spiral threads, axial ribs absent; next to the depressed area are 15 moderately broad axial ribs that fade anteriorly and posteriorly, entire whorl is covered with weak spiral ribs and secondary spiral threads. Siphonal canal short and straight, inner lip covered by thin inductura, columella with two columellar folds.

Etymology: The species name refers to the Paleocene Epoch.

Types: Holotype IGM 4541, paratypes IGM 4542, IGM 4543.

Measurements: Holotype IGM 4541, height $23.2 \mathrm{~mm}$, diameter $16.0 \mathrm{~mm}$; paratypes IGM 4542, height $12.2 \mathrm{~mm}$, diameter $7.8 \mathrm{~mm}$; IGM 4543, height $20.1 \mathrm{~mm}$, diameter $14.6 \mathrm{~mm}$.

Occurrence: Holotype IGM 4541 PU loc. 1334, paratype IGM 4542 PU loc. 1307, paratype IGM 4543 PU loc. 1300-2.

Remarks: The Mexican specimens have no similarities to any species that have been described from the Paleocene elsewhere. They differ from the new species described above in not being globose, having straight whorls, middle part of the last whorl depressed with spiral ribs, strong axial ribs, and a shorter siphonal canal.

\section{Cancellaria sp. 1}

Figures 2k, 1

Admete n. sp. Paredes-Mejía, 1989, p. 388, pl. 16, figs. 27, 28.

Description: Shell medium-sized, fusiform. Protoconch of two smooth whorls. Teleoconch of four convex whorls. Suture canaliculated. Sculpture of first and second whorls with eight broad axial ribs, interspaces smooth; third whorl with 10 broad axial ribs, interspaces with 12 spiral threads; last whorl with 12 broad rounded axial ribs, with interspaces as wide as the ribs, and with 22 primary and secondary spiral threads. Aperture broad, inner lip covered by thin inductura; columella with two strong closely spaced folds.

Measurements: Hypotype IGM 4636, height $18.0 \mathrm{~mm}$, diameter $11.4 \mathrm{~mm}$.

Occurrence: PU loc. 1305.

Remarks: The Baja California specimen is similar to Cancellaria quercollis (Harris) (1896, p. 199, pl. 8, fig. 4) from the Paleocene of Alabama, U.S.A. in the shape of the ribs; but differs in that the spiral threads do not occur in pairs in all the whorls, and do not have a nodose appearance. The Mexican specimen is more convex than the one from Alabama. It is similar to Cancellaria deperdita Michelotti (Sacco, 1894, p. 53, pl. 3, fig. 38) from the Oligocene of Italy, in having the same size and same number of equal ribs.

\section{Cancellaria sp. 2}

Figures 2m, n

Bonellitia (Admetula) paucivaricata (Gabb, 1864). ParedesMejía, 1989, p. 390, pl. 16, figs. 29, 30.

Description: Shell small-sized, globose. Protoconch of 


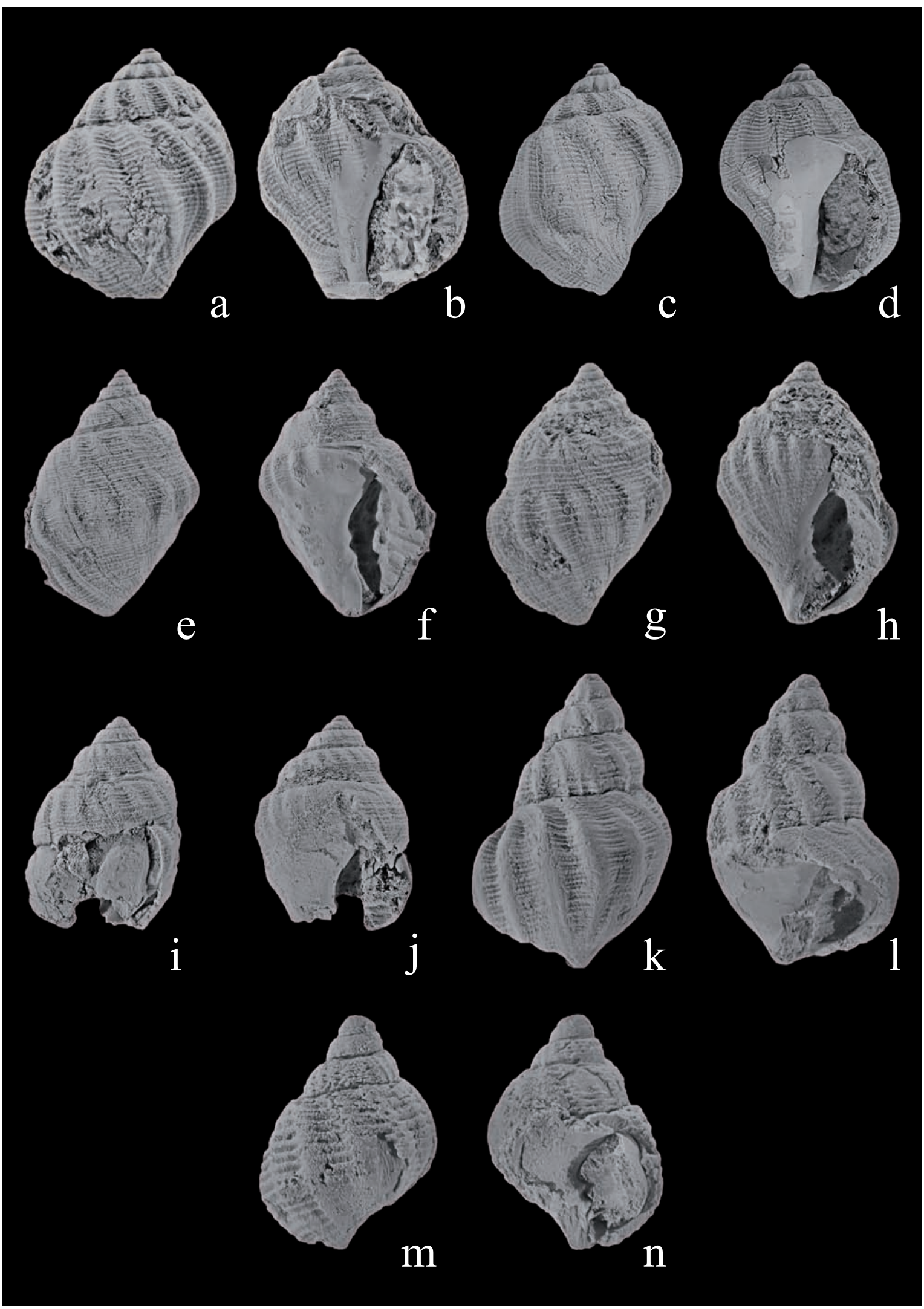

Figure 2. a-d. Cancellaria bajaensis sp. nov. a: holotype IGM 4539, adapertural view, x2.1; b: apertural view, x2.1; c: paratype IGM 4540, adapertural view, x2.0; d: apertural view, x2.0; e-j, Cancellaria paleocenica sp. nov. e: holotype IGM 4541, adapertural view, x2.0; f: apertural view, x2.0; g: paratype IGM 4542, adapertural view, x4.4; h: apertural view, x4.4; i: paratype IGM 4543, adapertural view, x2.0; j: apertural view, x2.0; k, 1, Cancellaria sp. 1, k: hypotype IGM 4636, adapertural view, x3.1; 1: apertural view, x3.1; m, n, Cancellaria sp. 2, m: hypotype IGM 4637, apertural view, x5.0; n: adapertural view x5.0. 
two smooth whorls. Teleoconch of two and a half whorls. Suture canaliculated. Sculpture of first whorl about 14 axial ribs and four spiral ribs. Last whorl with 10 axial ribs and 14 spiral ribs that cross over the axial ribs. Aperture broad, columellar plait with two strong folds.

Measurements: Hypotype IGM 4637, height $8.7 \mathrm{~mm}$, diameter $5.8 \mathrm{~mm}$.

Occurrence: PU loc. 1320.

Remarks: The Mexican specimen is not Bonellitia (Admetula) paucivaricata (Gabb, 1864), p. 95, pl. 28, figs. 209, 209a from the Eocene of California, U.S.A., because it presents neither varices nor secondary fine spiral ribs in the posterior three spaces, nor are there two secondary spiral threads in the posterior interspaces of the last whorl, and a single rib is present each of the next two interspaces. It has the same sculpture as Cancellaria bajaensis sp. nov.

\section{Conclusions}

The fauna studied is represented by one genus of the gastropod family Cancellariidae. The composition of the fauna compared with fauna of the same age in North and Central California shows that the Mesa San Carlos area is characterized by tropical conditions.

\section{Acknowledgements}

This work has been supported by the Programa de Apoyo a Proyectos de Investigación e Innovación Tecnológica (PAPIIT) UNAM IN 102314 ¿Existió el protogolfo de California en el Mioceno medio?

We would like to thank the following persons: L.M. Paredes-Mejía and W.J. Zinsmeister for collecting the material and giving us permission to publish the fauna. S. A. Quiroz-Barroso and an anonymous reviewer for the useful comments that improved the manuscript. J.M. Contreras for taking and processing the photographs and B. Martiny for revision of the English language.

\section{References}

Anderson, F.M., 1905, A stratigraphic study in the Mount Diablo Range of California, Proceedings of the California Academy of Sciences, Third Series: Geology, 2(2), 155-248.

Bouchet, P., Rocroi, J-P., Fryda, J., Hausdorf, B., Ponder, W., Valdés, Á., Warén, A., 2005, Classification and Nomenclator of Gastropod families: Malacologia, 47(1, 2), 1-397.

Emmons, S.F., Merrill, G.P., 1894, Geological sketch of Lower California: Bulletin of the Geological Society of America, 5, 489-514.
Forbes, E., Hanley, S., 1850-1853, A history of British Mollusca and their shells. Volume III. Including the families of Gastropoda from Neritidae to Elysiadae, London, Van Voorst, 616 p.

Gabb, W.M., 1864, Description of the Cretaceous Fossils, Geological Survey of California: Palaeontology, Volume 1, 55-217.

Gabb, W.M., 1866, Cretaceous and Tertiary Fossils. Section I, Part I. Description of the Tertiary invertebrate fossils: Geological Survey of California, Palaeontology, 2, 39-63.

Hanna, G.D., 1924, Rectification of nomenclature: Proceedings of the California Academy of Sciences, Fourth Series, 13(10), 151-186.

Hanna, G.D., 1927, An Eocene invertebrate fauna from the La Jolla Quadrangle, California, University of California Publications: Bulletin of the Department of Geological Sciences, 16(8), 247-398.

Harris, G.D., 1896, The Midway Stage: Bulletins of American Paleontology, $1(4), 115-270$.

Lamarck, J.B.P. de, 1799, Prodrome d'une nouvelle classification des coquilles, Mémoires de la Société d'Histoire Naturelle de Paris, 1, 63-91.

Linnaeus, C., 1767, Systema naturae per regna tria naturae. Editio duodecimo reformata: Stockholm, 1(2), 533-327.

Paredes-Mejia, L.M., 1989, Late Cretaceous - Early Cenozoic stratigraphy and paleontology (Mollusca: Gastropoda) of the Sepultura Formation, Mesa San Carlos, Baja California Norte, Mexico. University of Purdue, U.S.A. Ph.D. Thesis, 527 p.

Perrilliat, M.C., 2013a, Late Paleocene Architectonicidae (Gastropoda: Heterobranchia) from Baja California, Mexico: Revista Mexicana de Ciencias Geológicas, 30(1), 178-185.

Perrilliat, M.C., 2013b, Fossil gastropods from the Late Paleocene Sepultura Formation, Baja California, Mexico: Neues Jarhbuch für Geologie und Paläontologie Abhandlungen, 268, 127-148.

Sacco, F., 1894, I mollluschi dei terreni Terziarii del Piemonte e della Liguria. Part 16. Cancellariidae. Torino. C. Clausen, 78 p.

Santillán, M., Barrera, T., 1930, Las posibilidades petrolíferas en la costa occidental de la Baja California entre los paralelos $30^{\circ}$ y $32^{\circ}$ latitud norte: Anales Instituto Geológico de México, 5, 1-37.

Squires, R.L., 1988, Geologic Age refinements of West Coast Eocene Marine Mollusks, in Filewicz, M.V., Squires, R.L. (eds.), Paleogene stratigraphy, West Coast of North America, Pacific Section, S.E.P.M.: West Coast Paleogene Symposium, 581, 107-112.

Squires, R.L., Saul, L.R., 2006, New buccinoid gastropods from uppermost Cretaceous and Paleocene strata of California and Baja California, Mexico: The Nautilus, 120(2), 66-78.

Squires, R.L., Zinsmeister, W.J., Paredes-Mejía, L.M., 1989, Popenoeum, a new pseudolivine gastropod genus: widespread and most diversified during the Paleocene: Journal of Paleontology, 63, (2), 212-217.

Vokes, H.E., 1939, Molluscan faunas of the Domenguine and Arroyo Hondo Formations of the California Eocene: Annals of the New York Academy of Sciences, 38, 1-246.

White, C.A., 1889, On invertebrate fossils from the Pacific Coast: Bulletin of the United States Geological Survey, 51, 1-102.

Zinsmeister, W.J., Paredes-Mejía, L.M., 1988, Paleocene Biogeography of the West Coast of North America: A Look at the Molluscan Fauna from Sepultura Formation, Mesa San Carlos, Baja California, Norte, in Filewicz, M.V., Squires, R.L. (eds.), Paleogene Stratigraphy, West Coast of North America, Pacific Section, S.E.P.M., West Coast Paleogene Symposium, 58, 9-22.

Manuscript received: March 12, 2015

Corrected manuscript received: May 13, 2015

Manuscript accepted: May 18, 2015 